Original Article

\title{
TO STUDY THE PHARMACOKINETIC HERB-DRUG INTERACTION OF MOMORDICA CHARANTIA FRUIT EXTRACT AND PURE CHARANTIN WITH NATEGLINIDE IN RATS
}

\author{
AISHWARYA R. BALAP \\ Department of Pharmaceutical Chemistry, Progressive Education Society's Modern College of Pharmacy, Nigdi, Pune 411044, India \\ Email: balapaishwarya8@gmail.com
}

Received: 01 Feb 2021, Revised and Accepted: 30 Jul 2021

\section{ABSTRACT}

Objective: Momordica charantia fruit extract and antidiabetic drug Nateglinide might be used simultaneously in the treatment of diabetes, so the objective of this study was to investigate pharmacokinetic herb-drug interactions of Momordica charantia fruit extract and pure charantin with nateglinide in rats.

Methods: After oral co-administration of Momordica charantia fruit extract $(250 \mathrm{mg} / \mathrm{kg})$ and Charantin $(10 \mathrm{mg} / \mathrm{kg})$ with nateglinide in rats, drug concentration parameters peak plasma concentration $\left(\mathrm{C}_{\max }\right)$, time to reach peak plasma concentration $\left(\mathrm{t}_{\max }\right)$, elimination half-life $\left(\mathrm{t}_{1 / 2}\right)$, apparent volume of distribution (Vd), plasma clearance (Cl), and area under the curve (AUC) were calculated by using the non-compartment model.

Results: NAT was absorbed into the circulatory system and reached its peak concentration approximately $2 \mathrm{~h}$ after being administered individually. $t_{\max }$ of groups co-administered NAT+MCE has been changed to $4 \mathrm{~h}$. A significant decrease in C $\max$ of NAT from $16.28 \mu \mathrm{g} / \mathrm{ml}$ to $11.37 \mu \mathrm{g} / \mathrm{ml}$ and 10.37 $\mu \mathrm{g} / \mathrm{ml}$ with NAT with charantin and NAT with MCE groups, respectively. AUC of NAT decreased from $84.53 \mathrm{~h} / \mu \mathrm{g} / \mathrm{ml}$ to $53.63 \mathrm{~h} / \mu \mathrm{g} / \mathrm{ml}$ and 47.17 $\mathrm{h} / \mu \mathrm{g} / \mathrm{ml}$ by co-administration with Charantin and MCE respectively. Co-administration of nateglinide with Charantin and Momordica charantia fruit extract decreased systemic exposure level of nateglinide in vivo with decreasing $\mathrm{C}_{\max }$ and AUC and an increase in $\mathrm{t}_{1 / 2}, \mathrm{Cl}$ and $\mathrm{Vd}$.

Conclusion: From this study, it can be concluded that nateglinide, Momordica charantia fruit extract, and pure Charantin existed pharmacokinetic herb-drug interactions in the rat which has to be correlated with the anti-diabetic study. Further studies should be done to understand the effect of other herbal ingredients of Momordica charantia fruit extract on nateglinide as well as to predict the herb-drug interaction in humans.

Keywords: Momordica charantia extract, Charantin, NAT, Pharmacokinetic herb-drug Interaction

(C) 2021 The Authors. Published by Innovare Academic Sciences Pvt Ltd. This is an open access article under the CC BY license (https://creativecommons.org/licenses/by/4.0/) DOI: https://dx.doi.org/10.22159/ijpps.2021v13i9.40976. Journal homepage: https://innovareacademics.in/journals/index.php/ijpps.

\section{INTRODUCTION}

Nateglinide ((2R)-3-phenyl-2-[(4-propan-2-ylcyclohexanecarbonyl) amino]propanoic acid.) (NAT fig. 1) belongs to class of meglitinide used in the treatment of diabetes [1-3]. Momordica charantia (MC) is a part of the cucurbitaceae family. It grows in tropical areas of India, Amazon, East Africa, Asia, and South America. MC contains a collection of biologically active chemicals, including alkaloids, saponins, flavonoids, triterpenes, proteins, and acids. The plant possesses anti-tumorous hypoglycemic, anti-bacterial, anti-parasitic, anti-viral, anti-fertility, and anti-carcinogenic properties. Fruits are used as a traditional medication for the treatment of diseases like illness of the liver, worms, colic spleen, rheumatism, gout, and also useful in the treatment of diabetes and cancer. It is a potent hypoglycemic agent due to the presence of insulin and alkaloids like a mixture of steroidal sapogenins and peptides known as charantin. $\mathrm{MC}$ is the most common plant used as anti-diabetic [4-7]. Charantin (fig. 1), an active constituent in the fruits of this medicinal plant, has been reported to have potential hypoglycemic activity [8].

Many polyherbal formulations, consisting of charantin as the main ingredient as anti-diabetic, are available in local Indian markets. In the treatment of diabetes, it is common practice that herbal formulations are either taken with or without the knowledge of health care providers, by the patients for good therapeutic effects. This may lead to either useful or toxic effects. Increasing consumption of medicinal herbs, which are often administered in combination with conventional therapeutic drugs, constituents in herbal preparations may be substrates, inhibitors, or inducers of cytochrome P450 enzymes (CYPs) and have an impact on the pharmacokinetics and pharmacodynamics of any co-administered drugs metabolized by this system [9]. Many studies reported for interaction between Momordica charantia extract (MCE) with various synthetic drugs [10-13]. Unfortunately, not a single attempt has been done to investigate the interaction study of MC and it's one of the major constituent Charantin with NAT, after oral administration in rats. Previously reported literature is present for the bioanalytical method for determining NAT in rats and humans [14-18]. However, there is no analytical method is available for simultaneous estimation of Charantin and NAT. Prompted by the above findings, an attempt to develop a new validated HPLC method for simultaneous determination of Charantin and NAT in rat plasma and application of the developed method for pharmacokinetic study in rats has been done. The study aimed to investigate the herb-drug interactions of MCE and Charantin with NAT by comparing their pharmacokinetic profiles after oral administration in rats.

\section{MATERIALS AND METHODS}

Chemicals and reagents

Plant extract

MCE was purchased from Green Heaven Pvt. Ltd, Nagpur (Batch No.:FG/BME/130417/1). All the tests like identification, moisture, acid-insoluble ash, bulk density, tapped bulk density, heavy metals, microbiology test, residual solvent analysis, pesticide residue analysis, and phytochemical analysis were within limits.

\section{Chemicals}

Charantin was purchased from Green Heaven Pvt. Ltd, Nagpur; Nateglinide and Repaglinide were procured from Yarrow Chem. Products, Mumbai.

\section{Animals}

Six female Wistar rats weighing 180-200 gm were purchased from the National Institute of Biosciences. The rats were kept in room temperatures $\left(25 \pm 2{ }^{\circ} \mathrm{C}\right)$ with $12 \mathrm{~h}$ night cycles $(12 \mathrm{~h} / 12 \mathrm{~h})$. The animals had free access to food and water. After acclimatization for 
$7 \mathrm{~d}$ ' animals were fasted overnight (12 h) before each experiment. All experiments were performed as per the guidelines of CPCSEA after approval (MCP/IAEC/008/2018) from the Institutional Animal Ethics Committee.<smiles>CC(C)CCCC(C)C1CCC2C3CC=C4CC(OC5OC(CO)C(O)C(O)C5O)CCC4(C)C3CCC12C</smiles>

A

B

Fig. 1: Chemical structures of Charantin (A) and Nateglinide (B)

\section{In vivo pharmacokinetic study in rats}

\section{Drug administration and blood sampling}

Experimental animals were divided into three groups of 18 animals of each as follows. Oral administration of Group 1-NAT alone (10 $\mathrm{mg} / \mathrm{kg}$, p. o.), Group 2-co-administration of Charantin with NAT (10 $\mathrm{mg} / \mathrm{kg}+10 \mathrm{mg} / \mathrm{kg}$, p. o.) and Group 3-co-administration of MCE with NAT $(250 \mathrm{mg} / \mathrm{kg}+10 \mathrm{mg} / \mathrm{kg}$, p. o.) for $7 \mathrm{~d}$. After drug administration, 18 animals were further subdivided into three groups with six animals each. Blood samples (1 $\mathrm{ml}$ each) were collected at $0,1.5,4$, and $10 \mathrm{~h}$ in the first subgroup, $0.5,2,6$, and $12 \mathrm{~h}$ in the second subgroup, and $1,3,8$, and $24 \mathrm{~h}$ in the third subgroup. Only four blood samples were collected from the individual animal within $24 \mathrm{~h}$ from the retro-orbital plexus under light ether anesthesia. The samples were transferred to EDTA tubes and centrifuged at 15000 rpm for $20 \mathrm{~min}$. Plasma was separated from the blood and stored at $-80^{\circ} \mathrm{C}$ until further analysis.

\section{Sample preparation}

$10 \mu$ l of each solution of Charantin and NAT added into $400 \mu$ ldrugfree plasma separately. For each calibration standard, $10 \mu \mathrm{l}$ of internal standard (I. S.) Repaglinide $(250 \mu \mathrm{g} / \mathrm{ml})$ solution was added and vortexed for $2 \mathrm{~min} .1 .5 \mathrm{ml}$ of ethyl acetate was added to each calibration standard and vortexed for $2 \mathrm{~min}$. After centrifugation at $15000 \mathrm{rpm}$ for $30 \mathrm{~min}$, the supernatant was transferred to another prelabelled polypropylene tubes and the solvent evaporated to dryness under a gentle stream of nitrogen gas at $35^{\circ} \mathrm{C}$. The residue, reconstituted with $200 \mu \mathrm{l}$ of mobile phase, and a $20 \mu \mathrm{L}$ aliquot, was injected into the High-Performance Liquid Chromatography (HPLC) system for analysis. The quality control (QC) samples also prepared in the same manner at concentrations of 1,10 , and $50 \mu \mathrm{g} / \mathrm{ml}$ as a single batch at each concentration.

\section{HPLC analysis}

The chromatographic separation was performed using an HPLC binary gradient system equipped with an autosampler system and a UV detector UV-3000-M with a Grace C18 column $(250 \mathrm{~mm}$ x 4.6ID, Particle size: $5 \mu \mathrm{m}$ ). The mobile phase system was optimized to give a good resolution of Charantin, NAT, and Repaglinide (I. S.) from other endogenous substances in the plasma sample. The mobile phase consisted of the mixture of solvent A (Methanol), solvent B (10 mmol Phosphate Buffer) in the ratio of $80: 20(\mathrm{v} / \mathrm{v})$ for $18 \mathrm{~min}$ at a flow rate of $1 \mathrm{ml} / \mathrm{min}$. The NAT, Charantin, and I. S. were detected at 7.5, 9.7, and $12.8 \mathrm{~min}$, respectively (fig. 2). The concentration of Charantin was determined using the peak area ratio of pure Charantin to I. S. The concentration of Charantin in MCE was determined using the peak area ratio of Charantin in MCE and I. S. Similarly, the concentration of NAT was determined using the peak area ratio of NAT and I. S. Further validation of the method was done according to the US Food and Drug Administration (USFDA) guidelines for selectivity, matrix effects, recovery, and stability [19].

\section{Data analysis}

Data analysis performed using Graph Pad Prism version 7.04 (Graph Pad Software Inc., USA). The peak plasma concentration $\left(\mathrm{C}_{\max }\right)$ and time reaching $\mathrm{C}_{\max }\left(\mathrm{t}_{\max }\right)$ read directly from the observed individual plasma concentration-time data. All data expressed as mean \pm Standard error of the mean (SEM). Differences between groups were evaluated by two-way Analysis of variance (ANOVA) (Bonferroni test). The differences are considered significant at ${ }^{*} \mathrm{P}<0.05$.

\section{RESULTS}

The developed HPLC method was validated as per USFDA guidelines. Typical equations of the calibration curves of Charantin and NAT obtained $\mathrm{y}=0.0384 \mathrm{x}+0.2751$ and $\mathrm{y}=0.0538 \mathrm{x}+0.3758$ respectively with good correlation coefficient ( $\mathrm{r} 2=0.9923$ and 0.9991 respectively). Intra and inter batch precisions within limits (R. SD < $15 \%)$ and accuracy was in between the range, 85 to $115 \%$. The developed HPLC method was applied successfully to the pharmacokinetic study in the rat plasma for the respective groups. The mean plasma concentration-time curves are shown in fig. 3 and the pharmacokinetic parameters are shown in table 1. NAT absorbed into the circulatory system and reached its peak concentration approximately $2 \mathrm{~h}$ after administered individually. $\mathrm{t}_{\max }$ of groups co-administered NAT+Charantin was the same, but $t_{\max }$ of group co-administered NAT+MCE has been changed to $4 \mathrm{~h}$, respectively. A significant decrease in $\mathrm{C}_{\max }$ of NAT from $16.28 \mu \mathrm{g} / \mathrm{ml}$ to $11.37 \mu \mathrm{g} / \mathrm{ml}$ and $10.37 \mu \mathrm{g} / \mathrm{ml}$ with NAT with charantin and NAT with MCE groups, respectively. AUC of NAT decreased from 84.53 $\mathrm{h} / \mu \mathrm{g} / \mathrm{ml}$ to $53.63 \mathrm{~h} / \mu \mathrm{g} / \mathrm{ml}$ and $47.17 \mathrm{~h} / \mu \mathrm{g} / \mathrm{ml}$ by co-administration with Charantin and MCE, respectively. Fast elimination of NAT was observed with increased $t_{1 / 2}$ from 9.18 to $11.72 \mathrm{~h}, \mathrm{Vd}$, from 0.11 to $0.37 \mathrm{~L}$ and $\mathrm{Cl}$ from 0.08 to $0.22 \mathrm{~L} / \mathrm{h}$ when co-administered with Charantin. Whereas $\mathrm{t}_{1 / 2}$ of NAT increased from 9.18 up to $11.80 \mathrm{~h}, \mathrm{Vd}$ from 0.11 to $5.51 \mathrm{~L}$ and $\mathrm{Cl}$ from 0.08 to $0.32 \mathrm{~L} / \mathrm{h}$ when coadministered with MCE. Co-administration of NAT with Charantin significantly $(\mathrm{P}<0.05)$ decreased the $\mathrm{C}_{\max }, \mathrm{t}_{\max }$, Area Under the Curve (AUC), Elimination rate constant (Ke) and increased the elimination half-life $\left(\mathrm{t}_{1 / 2}\right)$, apparent volume of distribution (Vd), and plasma clearance (Cl) of NAT when compared to NAT alone group. Coadministration of NAT with MCE significantly $(\mathrm{P}<0.05)$ decreased the $\mathrm{C}_{\max }$, AUC, Ke and increased the $\mathrm{t}_{\max }, \mathrm{t}_{1 / 2}, \mathrm{Cl}$, and Vd of NAT when compared to NAT alone group. These results indicated slow metabolism for nateglinide and a better volume of distribution has been achieved in the combination groups.

Where oral administration of,

Group 1-NAT alone (10 mg/kg, p. o.),

Group 2-co-administration of NAT (10 mg/kg, p. o.) with Charantin $(10 \mathrm{mg} / \mathrm{kg}$, p. o.) and

Group 3-co-administration of NAT (10 mg/kg, p. o) with MCE (250 $\mathrm{mg} / \mathrm{kg}$, p. o.). 


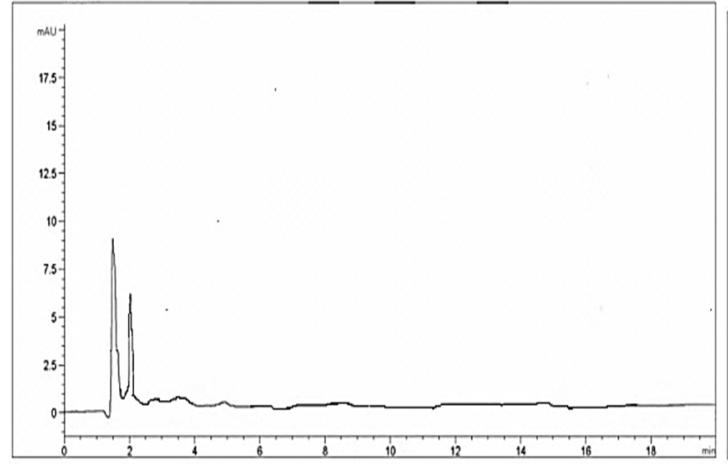

A

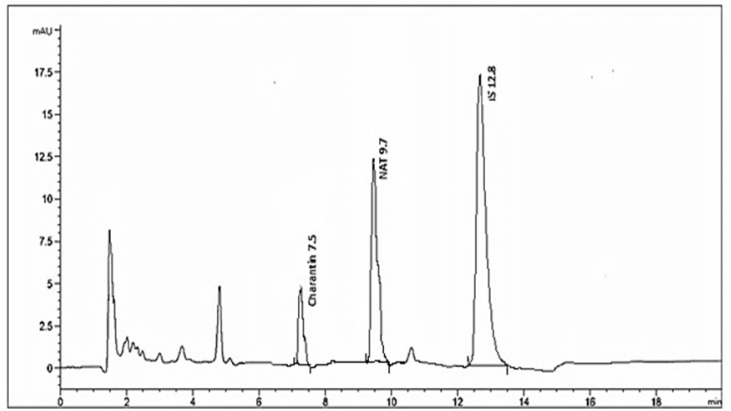

C

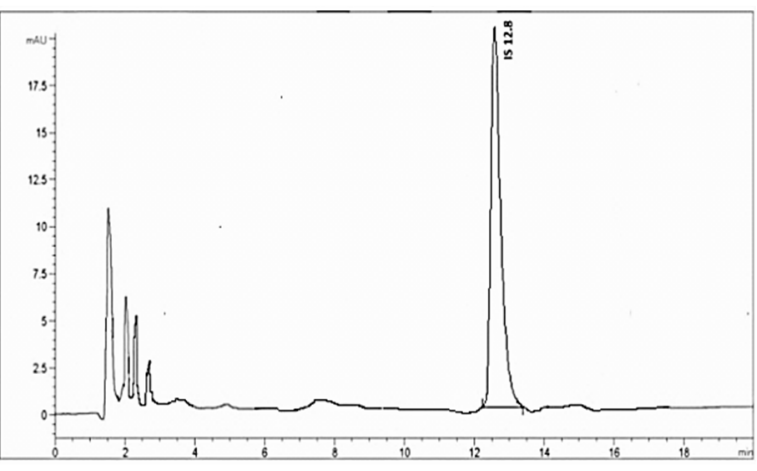

B

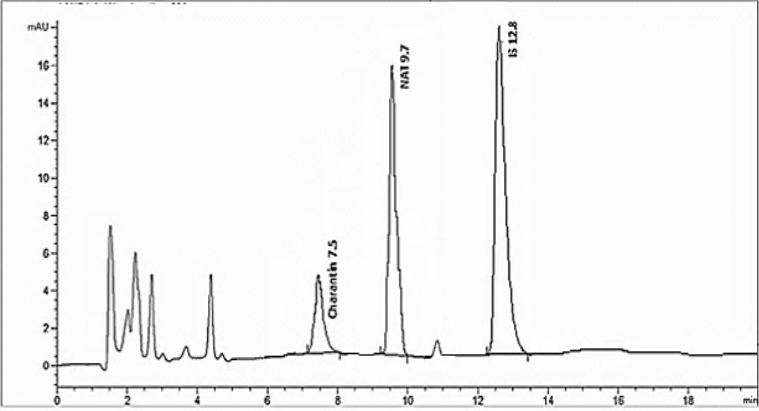

Fig. 2: Chromatogram of (A) blank plasma sample (B) blank plasma sample with Repaglinide (I. S.) (C) plasma sample spiked with NAT (10 $\mu \mathrm{g} / \mathrm{ml})$, Charantin $(10 \mu \mathrm{g} / \mathrm{ml})$ and I. S. (D) a plasma sample obtained from a rat at $2 \mathrm{~h}$ after oral administration of $10 \mathrm{mg}$ of Charantin and $10 \mathrm{mg}$ of NAT, Where $\mathrm{I}$. $S .=$ Internal standard, $\mu \mathrm{g} / \mathrm{ml}=$ microgram per milliliter

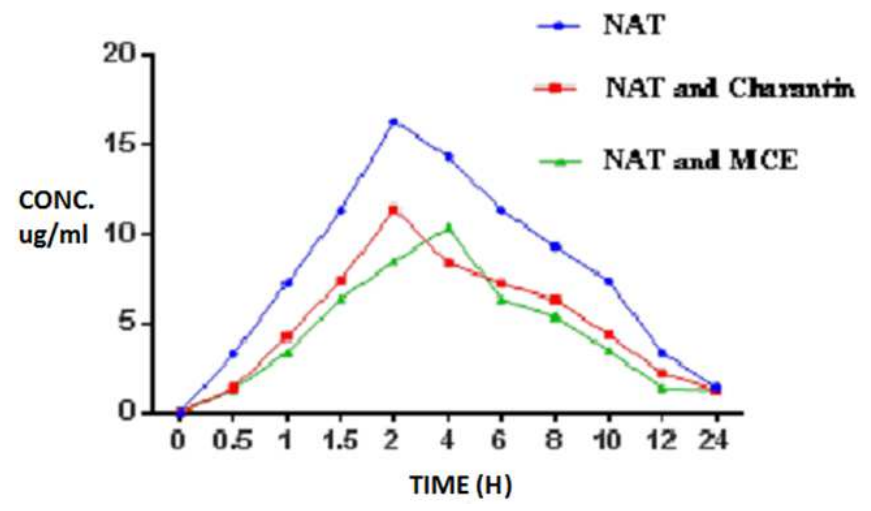

Fig. 3: Mean concentration-time curves of NAT (10 mg/kg, p. o.) alone, after co-administration of Charantin (10 mg/kg+10 mg/kg, p. o.) and after co-administration with MCE $(10 \mathrm{mg} / \mathrm{kg}+250 \mathrm{mg} / \mathrm{kg}, \mathrm{p} . \mathrm{o}$.$) , Where \mathrm{mg} / \mathrm{kg}=$ milligram per kilogram, $\mathrm{p} .0 .=$ by mouth

Table 1: Results of pharmacokinetic parameters of all the experimental groups

\begin{tabular}{llll}
\hline Parameters & NAT alone group 1 & NAT+Charantin group 2 & NAT+MCE group 3 \\
\hline $\mathrm{C}_{\max }(\mu \mathrm{g} / \mathrm{ml})$ & $16.28 \pm 0.27$ & $11.37 \pm 0.305$ & $10.37 \pm 0.311$ \\
$\mathrm{t}_{\max }(\mathrm{h})$ & 2 & 2 & 4 \\
$\mathrm{AUC}(\mathrm{h} / \mu \mathrm{g} / \mathrm{ml})$ & $84.53 \pm 0.628$ & $53.63 \pm 0.641$ & $47.17 \pm 0.674$ \\
$\mathrm{Ke}(1 / \mathrm{h})$ & $0.075 \pm 0.032^{*}$ & $0.059 \pm 0.028^{*}$ & $0.058 \pm 0.023^{*}$ \\
$\mathrm{t}_{1 / 2}(\mathrm{~h})$ & $9.18 \pm 0.052$ & $11.72 \pm 0.047^{*}$ & $11.80 \pm 0.043^{*}$ \\
$\mathrm{Vd}(\mathrm{L})$ & $0.11 \pm 0.04^{*}$ & $0.37 \pm 0.04^{*}$ & $5.51 \pm 0.11$ \\
$\mathrm{Cl}(\mathrm{L} / \mathrm{h})$ & $0.08 \pm 0.05$ & $0.22 \pm 0.03^{*}$ & $0.32 \pm 0.00^{*}$ \\
\hline
\end{tabular}

Data are expressed as mean \pm SD; $n=6$ rats per group. One-way ANOVA followed by Dunnett's test. ${ }^{*}<<0.05$, when group 2 and 3 compared to group 1., Where $\mu \mathrm{g} / \mathrm{ml}=$ microgram per milliliter, $\mathrm{h}=$ hour, $\mathrm{h} / \mu \mathrm{g} / \mathrm{ml}=$ hour per microgram per milliliter, $1 / \mathrm{h}=$ litre per hour, $\mathrm{L}=\mathrm{Litre}$. SD= Standard deviation, $\mathrm{ANOVA}=$ Analysis of variance, $\mathrm{n}=$ number . 


\section{DISCUSSION}

MC (Cucurbitaceae) has been used for the treatment of Diabetes. Various herb-drug interaction studies of MCE with antidiabetic drugs metformin, glibenclamide in diabetic rats and mice have been reported previously [8-11]. Charantin is the main the lead compound in MCE. Charantin and MCE are used for diabetes. Pharmacokinetic drug food interaction study of Nateglinide and Pomegranate Fruit Juice has been reported previously [20]. Also, the effect of Cilostazol, a CYP2C9 inhibitor, on pharmacokinetics of Nateglinide in wistar rats has been reported [21]. Not a single article is available for the pharmacokinetic interaction of Nateglinide with MCE and Charantin. This research work is the first attempt to study the pharmacokinetic interaction of Nateglinide with MCE and Charantin in wistar rats.

NAT is metabolized by the microsomal enzyme CYP2C9, whereas MCE is an inhibitor of the CYP2C9 enzyme. By inhibiting metabolism, MCE can increase the activity of NAT. Thus, the hypothesis that any substance influencing the CYP2C9 enzyme affects the metabolism of NAT in rats, which should be studied.

As per hypothesis, pharmacokinetic interactions were found by a significant decrease in $\mathrm{C}_{\max }$ of NAT from $16.28 \mu \mathrm{g} / \mathrm{ml}$ to $11.37 \mu \mathrm{g} / \mathrm{ml}$ and $10.37 \mu \mathrm{g} / \mathrm{ml}$ with NAT with charantin and NAT with MCE groups, respectively. Decrease in AUC of NAT was observed from 84.53 $\mathrm{h} / \mu \mathrm{g} / \mathrm{ml}$ to $53.63 \mathrm{~h} / \mu \mathrm{g} / \mathrm{ml}$ and $47.17 \mathrm{~h} / \mu \mathrm{g} / \mathrm{ml}$ by co-administration with Charantin and MCE, respectively. Fast elimination of NAT was observed with increased $t_{1 / 2}$ from 9.18 to $11.72 \mathrm{hr}$, Vd from 0.11 to $0.37 \mathrm{~L}$ and $\mathrm{Cl}$ from 0.08 to $0.22 \mathrm{~L} / \mathrm{h}$ when co-administered with Charantin. Whereas $t_{1 / 2}$ of NAT increased from 9.18 up to $11.80 \mathrm{~h}, \mathrm{Vd}$ from 0.11 to $5.51 \mathrm{~L}$ and $\mathrm{Cl}$ from 0.08 to $0.32 \mathrm{~L} / \mathrm{h}$ when co-administered with MCE. Co-administration of NAT with Charantin and MCE decreased the systemic exposure level of NAT in vivo, with decreasing $\mathrm{C}_{\max }$ and AUC, but increased $\mathrm{t}_{1 / 2}$ is significantly more with NAT+MCE treated group compared to NAT+Charantin treated group. These results indicated slow metabolism for NAT and a better volume of distribution has been achieved in the combination group.

Previously food-drug and drug-drug interactions of NAT have been reported and in results, it was observed that $\mathrm{C}_{\max }$ and AUC of NAT were increased after co-administration with pomegranate juice, whereas $\mathrm{C}_{\max }$ of NAT was decreased and no significant change in AUC of NAT was observed after co-administration with cilostazol. Consequence of CYP inhibition is an increase in the plasma concentration of the parent drug. Previous studies also reported increases in AUCs with co-administration of drugs inhibiting CYP isoenzymes exceeded up to $50 \%$ for nateglinide [22-23]. NAT is metabolized majorly by the microsomal enzyme CYP2C9 and to a lesser extent via CYP3A4. Based on results of this study and previous literature, other cytochromes, P-gp levels, components in MCE and various genotypic and phenotypic factors might be interfering with the metabolism, which should be studied further [24].

We hypothesized that co-administration of MCE or Charantin may affect the CYP450 family of enzymes and a herb-drug interaction will impact the pharmacokinetics of NAT. However, further study is needed to establish interactions in humans.

\section{CONCLUSION}

In conclusion, the results obtained from the study suggested that NAT with MCE and pure Charantin existed pharmacokinetic herbdrug interactions in the rat. A significant decrease in $\mathrm{C}_{\max }, \mathrm{AUC}$, and increase in $\mathrm{t}_{1 / 2}, \mathrm{Vd}, \mathrm{Cl}$ of NAT was observed after co-administration with pure Charantin and MCE. In anti-diabetic studies, even though the dose of Charantin is equal in both groups treated with MCE and Charantin, there was better activity observed with MCE treated group. The study observed that co-administration of Charantin and MCE changes the pharmacokinetics of NAT. Further studies should be done to understand the effect of other herbal ingredients of MCE and various genotypic and phenotypic factors on NAT, as well as to predict the herb-drug interactions in humans. Physicians and patients using MC should know its possible herb-drug interaction with NAT. The study provided valuable information for the rational use of herbal remedies in the treatment of diabetes.

\section{ACKNOWLEDGMENT}

The authors are thankful to Pooja Sathe and RAP analytical research and training center Nashik for helping in Pharmacokinetic method development and validation. The authors are also thankful to the Principal, Modern College of Pharmacy, Pune for providing instrumental and infrastructure facility to carry out the research work

\section{FUNDING}

Nil

\section{AUTHORS CONTRIBUTIONS}

Aishwarya Balap was associated in supervising, advising, positioning, and structuring the manuscript; All authors read and made corrections to the finalized manuscript before submission.

\section{CONFLICT OF INTERESTS}

This research does not have any conflict of interest with anyone or any institute.

\section{REFERENCES}

1. Phillips LS, Dunning BE. Nateglinide (Starlix): update on a new antidiabetic agent. Int J Clin Pract 2003;57:535-41.

2. Jain R, Jain P, Jain P. A review on treatment and prevention of diabetes mellitus. Int J Curr Pharm Res 2016;8:16-8.

3. Tentolouris N, Voulgari C, Katsilambros N. A review of nateglinide in the management of patients with type 2 diabetes. Vasc Health Risk Manag 2007;3:797-807.

4. Mahmoud MF, Ashry FE, Maraghy NN, Fahmy A. Studies on the antidiabetic activities of Momordica charantia fruit juice in streptozotocin-induced diabetic rats. Pharm Biol 2017;55:758-65.

5. Saifi AK, Chauhan NR, Dwivedi J. Evaluation of pharmacognostical, phytochemical and antidiabetic activity fruits of momordica charantia linn. Asian J Pharm Clin Res 2014;7:152-6.

6. Grover JK, Yadav SP. Pharmacological actions and potential uses of Momordica charantia: a review. J Ethnopharmacol 2004;93:123-32.

7. Virdi J, Sivakami S, Shahani S, Suthar A, Banavalikar M, Biyani M. Antihyperglycemic effects of three extracts from Momordica charantia. J Ethnopharmacol 2003;88:107-11.

8. Desai S, Tatke P. Charantin: an important lead compound from Momordica charantia for the treatment of diabetes. J Pharmacogn Phytochem 2015;3:163-6.

9. Zhou S. Interactions of herbs with cytochrome P450. Drug Metab Rev 2003;35:35-98.

10. Tripathi P, Gupta PP, Lal VK. Interaction of Momordica Charantia with metformin in diabetic rats. Am J Pharmacol Toxicol 2013;8:102-6.

11. Pramesthi A. Drug-herb interaction between metformin and Momordica Charantia in diabetic mice. Diabetes Obes Int J 2019;4:000203.

12. Gupta RC, Chang D, Nammi S, Bensoussan A, Bilinski A, Roufogalis BD. Interactions between antidiabetic drugs and herbs: an overview of mechanisms of action and clinical implications. Diabetol Metab Syndr 2017;9:59.

13. Abdel Rahman RF, Soliman GA, Saeedan AS, Ogaly HA, Abd Elsalam RM, Alqasaumi SI, et al. Molecular and biochemical monitoring of the possible herb-drug interaction between Momordica charantia extract and glibenclamide in diabetic rats. Saudi Pharm J 2019;27:803-16.

14. Masafumi T, Sachiko S, Naomi K, Yoichi K. Pharmacokinetics of nateglinide enantiomers and their metabolites in goto-kakizaki rats, a model for type 2 diabetes mellitus. Chirality 2010;22:92-8.

15. Pani NR, Nath L, Singh AK, Mahapatra SK. Development and validation of an analytical method for the estimation of nateglinide in rabbit plasma. J Pharm Anal 2012;2:492-8.

16. Bauer S, Stormer K, Kirchheiner J, Michael C, Brockmller J, Roots I. Rapid and simple method for the analysis of nateglinide in human plasma using HPLC analysis with UV detection. J Pharm Biomed Anal 2003;3:551-5.

17. Inoue $\mathrm{T}$, Shibahara $\mathrm{N}$, Miyagawa K. Pharmacokinetics of nateglinide and its metabolites in subjects with type 2 diabetes mellitus and renal failure. Clin Nephrol 2003;60:90-5. 
18. Ismail K, Rao AL. Validation of a developed analytical method for determination of nateglinide and metformin hcl in pure and pharmaceutical dosage form by reversed-phase highperformance liquid chromatography and its degradation studies. Asian J Pharm Clin Res 2021;14:196-202.

19. Guidance for industry, bioanalytical method validation, U. S. Department of health and human services, food and drug administration center for drug evaluation and research; 2018.

20. Shaikh SD, Patel A, Patel MA, Ali SA. Pharmacokinetic drug-food interaction study of nateglinide and pomegranate fruit juice. Iranian J Diabetes Obesity 2020;12:203-9.

21. Kanthikiran VV, Veerraghavan S, Satheeshmanikandan TRS, Shraddha R, Potharaju S, Mallick P, et al. Effect of cilostazol on pharmacokinetics of nateglinide in wistar rats. Pharma Professionals 2011;2:27-34.

22. Scheen AJ. Drug-drug and food-drug pharmacokinetic interactions with new insulinotropic agents repaglinide and nateglinide. Clin Pharmacokinet 2007;46:93-108.

23. Cheng Y, Wang G, Zhang W, Fan L, Chen Y, Zhou H. Effect of CYP2C9 and SLCO1B1 polymorphisms on the pharmacokinetics and pharmacodynamics of nateglinide in healthy Chinese male volunteers. Eur J Clin Pharmacol 2013;69:407-13.

24. Derungs A, Donzelli M, Berger B, Noppen C, Krahenbuhl S, Haschke M. Effects of cytochrome P450 inhibition and induction on the phenotyping metrics of the basel cocktail: a randomized crossover study. Clin Pharmacokinet 2016;55:79-91. 